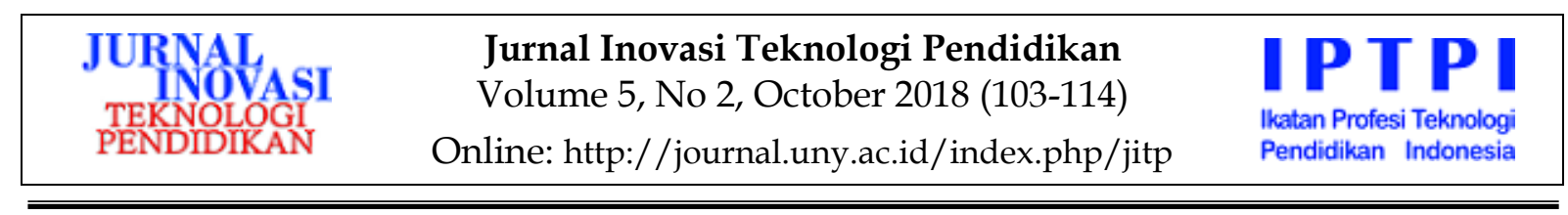

\title{
PENGEMBANGAN LEMBAR KERJA PESERTA DIDIK KIMIA BERBASIS INKUIRI TERBIMBING UNTUK KELAS XI IPA SMA/MA
}

\author{
Rina Rizalini ${ }^{1}{ }^{*}$, Herminarto Sofyan ${ }^{1}$ \\ 1Universitas Negeri Yogyakarta \\ 1J1. Colombo No. 1, Depok, Sleman 55281, Yogyakarta, Indonesia \\ * Corresponding Auhtor. Email: rinarizalini17@gmail.com
}

\begin{abstract}
Abstrak
Penelitian ini bertujuan untuk: (1) menghasilkan Lembar Kerja Peserta Didik (LKPD) kimia berbasis inkuiri terbimbing yang layak untuk peserta didik kelas XI IPA SMA, (2) mengetahui kepraktisan LKPD berbasis inkuiri terbimbing, dan (3) mengetahui keefektifan LKPD berbasis inkuiri terbimbing. Penelitian ini merupakan penelitian dan pengembangan yang menggunakan model Thiagarajan. Prosedur pengembangan meliputi tahap pendefinisian, perancangan, dan pengembangan. Tahap pendefinisian dilakukan survei untuk menganalisis permasalahan dan kebutuhan peserta didik. Tahap perancangan disesuaikan dengan kebutuhan dalam kegiatan pembelajaran. Tahap pengembangan dilakukan validasi ahli materi dan media kemudian diimplementasikan di kelas XI IPA SMAN 2 Wates pada 20 peserta didik. Hasil penelitian menunjukkan bahwa: (1) Hasil validasi LKPD kimia yang dikembangkan dikategorikan layak berdasarkan hasil validasi ahli materi dengan rerata skor 3,8 dan ahli media dengan rerata skor 4,0, (2) tingkat kepraktisan LKPD berada dalam kategori sangat baik, dan (3) keefektifan LKPD memperoleh sig < 0,05 membuktikan ada perbedaan yang signifikan antara kelas eksperimen dan kontrol.
\end{abstract}

Kata Kunci: lembar kerja peserta didik, kimia, inkuiri terbimbing

\section{DEVELOPING CHEMISTRY WORKSHEETS BASED ON GUIDED INQUIRY FOR THE SECOND GRADE STUDENTS OF SENIOR HIGH SCHOOL}

\begin{abstract}
This research study aims to: (1) produce valid chemistry worksheets based on guided inquiry for the second grade students of senior high school, (2) know the practically of worksheets based on guided inquiry, and (3) know the effectiveness of worksheets based on guided inquiry. This study was research and development using the Thiagarajan model. The procedure of the development included the steps of defining, designing, and developing. In the defining step, a survey to analyze the problems and student's needs. The designing step, was conducted the needs of the learning activities. The development step a validation was done by materials and media experts then implementation in class XI science of SMAN 2 Wates to 20 students. The result of the study shows: (1) the chemistry worksheets produced fullfills the appropriateness criteria based on the result of materials experts with the mean score 3.8 and media experts is 4.0 which is in a good category, (2) the practically level is in the very good category, and (3) the effectiveness of worksheets obtaining sig $<0.05$ proves there is a significant difference between the experimental and control class.
\end{abstract}

Keywords: worksheets, chemistry, guided inquiry

Permalink/DOI: http://dx.doi.org/10.21831/jitp.v5i2.14445 


\section{Pendahuluan}

Kecanggihan teknologi di zaman sekarang menuntut masyarakat untuk bisa mengikuti perkembangan sains dan teknologi. Pendidikan merupakan salah satu kunci yang dapat memberikan bekal pengetahuan untuk mengikuti perkembangan sains dan teknologi. Kualitas suatu pendidikan akan meletakkan dasar bagi kualitas masyarakat yang hidup dan dihidupi oleh sains dan teknologi. Oleh karena itu pendidikan senantiasa mengalami perkem-bangan dalam usahanya meningkatkan kualitas pelaksanaan dan hasil suatu proses pendidikan. Salah satu cara yang ditempuh adalah dengan menyempurnakan proses pembelajaran yang berlangsung agar lebih menekankan pada pembentukan sikap, keterampilan, dan pengetahuan.

Terdapat dua proses pembelajaran yang selama ini digunakan oleh pendidik yaitu proses pembelajaran langsung dan proses pembelajaran tidak langsung. Trianto (2007, p. 25) menyatakan pembelajaran langsung adalah proses peserta didik mengembangkan pengetahuan, kemampuan berpikir, dan keterampilan psikomotorik dengan pendekatan saintifik. Sedangkan proses pembelajaran tidak langsung adalah proses pembelajaran untuk mengembangkan moral dan perilaku yang terkait dengan sikap.

Sejalan dengan pemikiran diatas, Mata pelajaran Kimia merupakan salah satu mata pelajaran yang menekankan pada proses pembelajaran langsung untuk mengembangkan kemampuan peserta didik agar mampu menjelajahi dan memahami alam sekitar secara ilmiah. Belajar melalui pengalaman langsung lebih baik daripada hanya dengan menghafal suatu konsep. Hamalik (2011, p. 47) mengemukakan bahwa belajar merupakan suatu proses, suatu kegiatan, dan bukan suatu hasil atau tujuan. Oleh karena itu, sebaiknya belajar dilakukan dengan melakukan suatu kegiatan, misalnya eksperimen atau demonstrasi. Eksperimen tidak hanya sebatas pembuktian konsep, dapat juga untuk menemukan suatu konsep.
Permendiknas Tahun 2006 Nomor 22 (Menteri Pendidikan Nasional, 2006) dalam Standar Isi mata pelajaran kimia menekankan pada kemampuan pemahaman konsep kimia. Hal ini merupakan sesuatu yang sangat penting untuk dimiliki peserta didik dalam mencapai tujuan pembelajaran kimia. Kemampuan pemahaman konsep kimia yang dimiliki peserta didik memberikan kontribusi dalam menentukan hasil belajar peserta didik.

Observasi yang dilakukan di beberapa sekolah menunjukkan bahwa pola pembelajaran kimia di sekolah pada umumnya cenderung teacher-centered. Pendidik bertindak sebagai pemberi informasi secara aktif, sementara peserta didik pasif mendengarkan dan menyalin, sekali pendidik bertanya dan peserta didik menjawab, pendidik memberi contoh soal dilanjutkan dengan memberi soal latihan yang sifatnya rutin kurang melatih pemahaman peserta didik. Aktivitas pembelajaran seperti ini kurang melibatkan peserta didik dalam menemukan suatu konsep dalam proses pembelajaran. Padahal pembelajaran kimia menekankan pada pengalaman langsung yang bertujuan mengembangkan kompetensi agar peserta didik dapat memahami alam sekitar melalui proses "mencari tahu" dan "berbuat", hal tersebut tentu membantu peserta didik memperoleh pemahaman yang lebih mendalam (Zulfiani, Feronika, \& Kinkin, 2009, p. 46).

Berdasarkan hasil wawancara yang dilakukan dengan pendidik kimia SMAN 2 Wates diperoleh beberapa informasi yaitu: kurikulum yang digunakan di SMAN 2 Wates adalah Kurikulum 2013, sedangkan pemahaman konsep peserta didik pada mata pelajaran kimia masih rendah. Hal ini ditunjukkan dengan rata-rata nilai mata pelajaran kimia peserta didik masih di bawah standar ketuntasan belajar. Kriteria Ketuntasan Minimal (KKM) untuk mata pelajaran kimia dengan nilai 75 masih belum bisa dicapai oleh semua peserta didik. Terdapat 14 peserta didik dari 20 peserta didik yang nilainya masih kurang dari $\mathrm{KKM}$, dan hanya enam peserta didik 
yang nilainya sudah mencapai KKM yang ditentukan. Data tersebut menunjukkan bahwa hanya $22,5 \%$ dari jumlah peserta didik yang sudah memenuhi nilai KKM dan $52,5 \%$ dari jumlah peserta didik masih belum mencapai KKM.

Berdasarkan hasil observasi pembelajaran yang dilakukan secara umum teridentifikasi bahwa: Pertama, minat belajar peserta didik dalam pembelajaran kimia di SMAN 2 Wates masih kurang. Hal ini dibuktikan dengan peserta didik yang terlihat mengabaikan pelajaran dan asyik mengobrol dengan temannya saat pembelajaran kimia berlangsung. Kedua, bahan ajar yang digunakan pendidik di sekolah adalah bahan ajar cetak. Akan tetapi, pendidik masih menggunakan bahan ajar konvensional seperti halnya Lembar Kerja Peserta Didik (LKPD), yaitu LKPD yang hanya memuat konsep yang sudah jadi, sehingga peserta didik hanya menghafal dan tidak membangun konsep itu sendiri. Jika sumber belajar dan bahan ajar kurang menarik atau terkesan monoton, maka akan menurunkan kualitas pembelajaran sehingga pemahaman siswa tentang materi yang diajarkan menjadi terhambat (Lukman \& Ishartiwi, 2014, p. 110).

Kondisi pembelajaran selama ini di mana peserta didik hanya sebagai objek pembelajaran yang menerima informasi dari pendidik merupakan kendala yang relatif sulit untuk diubah. Namun demikian, ada beberapa cara yang dapat digunakan pendidik untuk dapat mengaktifkan peserta didik, salah satunya melalui penggunaan Lembar kerja peserta didik (LKPD). Penyajian pembelajaran kimia dengan menggunakan LKPD menuntut adanya partisipasi aktif dari para peserta didik, karena LKPD merupakan bentuk usaha pendidik untuk membimbing peserta didik secara terstruktur melalui kegiatan yang mampu memberikan daya tarik kepada peserta didik untuk mempelajari kimia.

Proses penemuan konsep erat kaitannya dengan pendekatan inkuiri, dan dalam hal ini pengembang menggunakan pendekatan inkuiri terbimbing sebagai dasar langkah dalam mengkonstruk konsep mengenai materi kimia yang dipelajari. Sujudi (2011, p. 84) menyatakan bahwa pembelajaran inkuiri merupakan pendekatan pembelajaran yang melibatkan peserta didik secara aktif dalam menemukan konsep, prinsip, dan teori.

Metode pembelajaran inkuiri adalah suatu rangkaian kegiatan belajar yang melibatkan secara maksimal seluruh kemampuan peserta didik untuk mencari dan menyelidiki secara sistematis, kritis, logis, analisis, sehingga mereka dapat me-rumuskan sendiri penemuannya dengan penuh percaya diri Trianto (2012, p. 166). Sasaran utama kegiatan pembelajaran dengan metode pembelajaran inkuiri adalah keterlibatan peserta didik secara maksimal dalam proses pembelajaran, keterarahan kegiatan yang logis dan sistematis pada tujuan pembelajaran dan mengembangkan sikap percaya diri peserta didik tentang apa yang ditemukan dalam pelaksanaan metode pembelajaran inkuiri (Sasongko \& Haryanto, 2016, p. 42).

Trowbridge \& Bybee (1996, p. 134) mengemukakan tiga macam pendekatan inkuiri yaitu: inkuiri terbimbing, inkuiri bebas, dan inkuiri terstruktur. Dari ketiga macam pendekatan inkuiri tersebut, jenis inkuiri yang cocok diterapkan untuk tingkatan SMA/MA adalah inkuiri terbimbing. Hal ini disebabkan perkembangan peserta didik SMA/MA termasuk ke dalam operasional formal. Pada tahap ini sebetulnya peserta didik sudah dapat memahami konsep dan dapat berfikir konkrit maupun abstrak, akan tetapi karena rentang usia siswa SMA masuk pada kategori pra-remaja sehingga secara psikologis belum stabil sehingga masih memerlukan bimbingan untuk membiasakannya dalam proses pencarian pengetahuan. Inkuiri terbimbing menyediakan lebih banyak arahan untuk para peserta didik yang belum siap menyelesaikan masalah dengan inkuiri tanpa bantuan karena kurangnya pengalaman dan pengetahuan atau belum mencapai tingkat perkembangan kognitif level abstrak. 
Penelitian ini bertujuan untuk: (1) menghasilkan LKPD kimia berbasis inkuiri terbimbing yang layak, (2) mengetahui kepraktisan LKPD kimia berbasis inkuiri terbimbing yang dikembangkan, dan (3) mengetahui keefektifan LKPD kimia berbasis inkuiri terbimbing yang dikembangkan.

\section{Metode Penelitian}

Penelitian ini menggunakan pendekatan kuantitatif dengan jenis penelitian pengembangan Research and Development $(\mathrm{R}$ \& D) yang mengacu pada model pengembangan Thiagarajan, Semmel, \& Semmel (1974, p. 2) yang terdiri dari tahap define, design, develop, and disseminate.

Pengambilan data pda penelitian ini dilaksanakan selama bulan Februari-Maret 2017. Lokasi penelitian dalam penelitian ini yaitu SMAN 2 Wates yang terletak di jalan Bendungan, Wates, Kulon Progo, Yogyakarta.

Subjek uji coba dalam penelitian ini adalah peserta didik kelas XI IPA SMAN 2 Wates semester 2 Tahun Ajaran 2016/2017. Adapun pembagiannya yaitu uji coba kelompok kecil sebanyak enam peserta didik, uji coba lapangan yaitu kelas XI IPA (kelas eksperimen, menggunakan LKPD kimia berbasis inkuiri terbimbing) dan kelas XI $\mathrm{IPA}_{4}$ (kelas kontrol, menggunakan pembelajaran langsung). Prosedur pengembangan LKPD ki-mia berbasis inkuiri terbimbing ini dapat dijelaskan dalam Gambar 1.

Data yang digunakan dalam penelitian pengembangan ini adalah data kuantitatif dan kualitatif yang kemudian dianalisis secara statistik deskriptif. Data kuantitatif diperoleh dari hasil validasi berupa skor penilaian dari ahli materi, ahli media, praktisi kimia, dan peserta didik dengan menggunakan skala lima dengan rentang nilai: 5 untuk kategori sangat baik, 4 untuk kategori baik, 3 untuk kategori cukup baik, 2 untuk kategori kurang baik, dan 1 untuk kategori tidak baik. Data kuantitatif juga diperoleh dari skor hasil pretest dan posttest. Sedangkan data kualitatif diperoleh melalui wawancara.

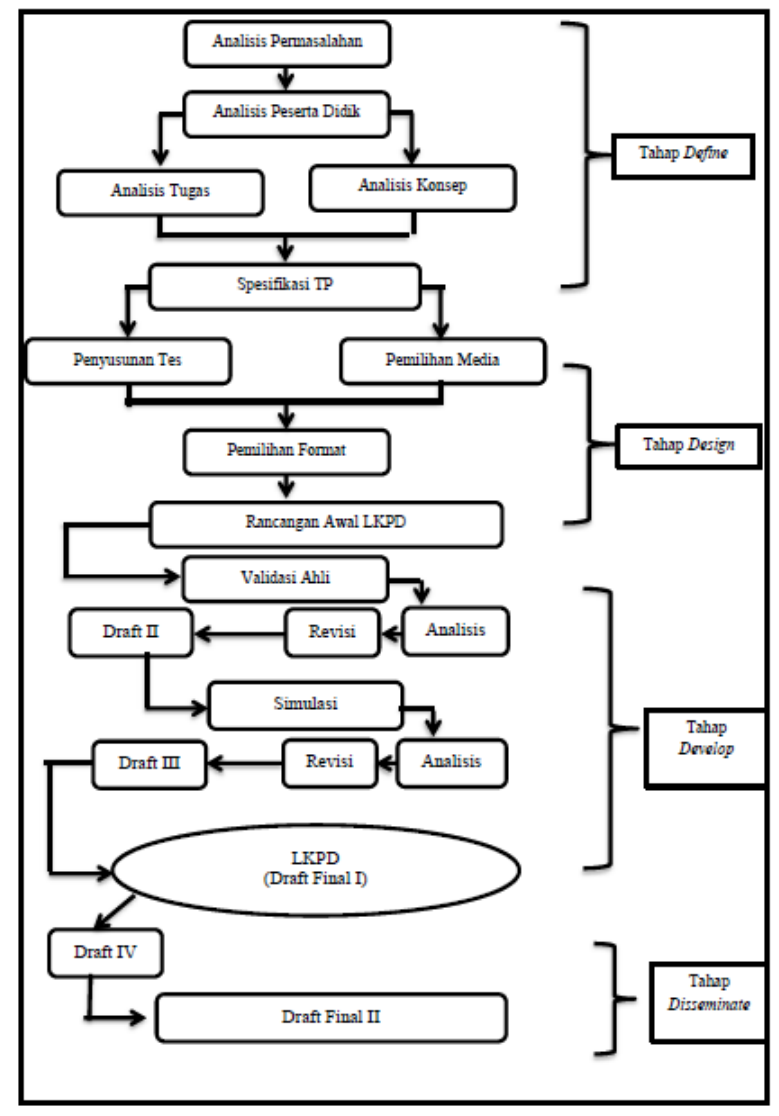

Gambar 1. Prosedur Pengembangan Lembar Kerja Peserta Didik Model 4-D

Teknik pengumpulan data yang digunakan dalam penelitian ini meliputi: interview, angket, observasi, dan soal pretest dan posttest. Interview dilakukan dengan mewawancarai pendidik mengenai proses pembelajaran kimia disekolah. Teknik pengumpulan data melalui angket dilakukan pada saat validasi ahli media dan materi, serta pada uji coba lapangan angket diisi oleh peserta didik. Observasi digunakan untuk mengetahui keterlaksanaan pembelajaran inkuiri terbimbing. Sedangkan soal pretest dan posttest digunakan untuk mengetahui keefektifan LKPD kimia.

Instrumen yang digunakan sebagai pengumpulan data berupa lembar validasi LKPD untuk ahli media dan materi, angket respon peserta didik, lembar keterlaksanaan pembelajaran inkuiri terbimbing, dan pretest dan posttest.

Teknik analisis data kelayakan LKPD kimia menggunakan skala likert. Skor 
yang diperoleh kemudian dikonversikan menjadi nilai dengan skala lima. Kelayakan LKPD hasil pengembangan baik dari aspek materi dan media, serta untuk mengetahui respon peserta didik terhadap LKPD kimia maka dari data yang mula-mula berupa skor diubah menjadi data kualitatif dengan skala lima. Adapun acuan pengubahan skor menjadi skala lima sebagai berikut.

Tabel 1. Konversi Skor pada Skala 5

\begin{tabular}{ccc}
\hline Nilai & Interval & Keterangan \\
\hline A & $4,50 \leq \bar{X} \leq 5,00$ & Sangat Baik \\
B & $3,50 \leq \bar{X}<4,50$ & Baik \\
C & $2,50 \leq \bar{X}<3,50$ & Cukup Baik \\
D & $1,50 \leq \bar{X}<2,50$ & Kurang Baik \\
E & $0,00<1,50$ & Tidak Baik \\
\hline
\end{tabular}

Teknik analisis data untuk mengetahui kepraktisan penggunaan produk hasil pengembangan dengan melihat nilai keterlaksanaan sintaks pembelajaran inkuiri terbimbing dan respon dari peserta didik. Deskripsi persentase keterlaksanaan model pembelajaran inkuiri terbimbing disajikan pada Tabel 2.

Tabel 2. Interval Kriteria Kepraktisan

\begin{tabular}{cc}
\hline Interval (\%) & Katergori \\
\hline $86-100$ & Sangat Baik \\
$71-85$ & Baik \\
$56-70$ & Cukup \\
$41-55$ & Kurang Baik \\
$\leq 40$ & Tidak Baik \\
\hline
\end{tabular}

Teknik analisis data untuk mengetahui keefektifan penggunaan LKPD kimia dengan melihat nilai gain skor dan persentase ketuntasan peserta didik. Peningkatan pemahaman konsep kimia peserta didik yang terjadi sebelum dan sesudah pembelajaran inkuiri terbimbing dihitung dengan rumus $N$-gain yang ditentukan berdasarkan rata-rata gain skor yang dinormalisasi yaitu perbandingan dari skor gain. Rata-rata gain yang dinormalisasi ( $N$-gain) (Hake, 1998, p. 68) dinyatakan oleh persamaan sebagai berikut.
Keterangan:

$$
g=\frac{S_{\text {post }}-S_{\text {pre }}}{S_{\text {maks }}-S_{\text {pre }}}
$$

$\mathrm{S}$ post : rata-rata skor posttest

S pre : rata-rata skor pretest

$S$ maks : skor maksimal

Interpretasi kriteria tingkat $N$-gain pada Tabel 3.

Tabel 3. Kategori Tingkat N-gain

\begin{tabular}{cc}
\hline Batasan & Kategori \\
\hline $\mathrm{g}>0,70$ & Tinggi \\
$0,30 \leq \mathrm{g} \leq 0,70$ & Sedang \\
$\mathrm{g}<0,30$ & Rendah \\
\hline
\end{tabular}

\section{Hasil dan Pembahasan}

Tahap pendefinisian bertujuan untuk mendefinisikan dan menetapkan syarat-syarat pembelajaran. Tahap pendefinisian ini terdiri dari lima langkah pokok, yaitu analisis permasalahan, analisis siswa, analisis tugas, analisis konsep/materi, dan spesifikasi tujuan pembelajaran.

Analisis permasalahan dilakukan di SMAN 2 Wates yang terletak di jalan Bendungan, Wates, Kulon Progo, Yogyakarta. Tujuannya adalah untuk memunculkan dan menetapkan masalah dasar yang dihadapi dalam pembelajaran kimia di sekolah tersebut, yang menghasilkan data berupa kebutuhan pengembangan bahan ajar yang berbasis pada peserta didik. Hasil wawancara dengan pendidik menyatakan bahwa SMAN 2 Wates menggunakan kurikulum 2013, menggunakan LKPD dan buku paket kimia yang dibeli dari agen buku. Hal ini tentunya beresiko karena tidak semua LKPD tersebut sesuai dengan kondisi sekolah dan kondisi peserta didik. Metode pembelajaran yang diterapkan adalah metode ceramah, diskusi, dan demonstrasi. Hasil pengamatan menunjukkan pendidik masih seringkali menjadi pusat pembelajaran. Hal tersebut serupa dengan penelitian yang dilakukan Rizhal Hendi Ristanto bahwa kebanyakan sekolah masih menerapkan pem- 
belajaran teacher centered sehingga peserta didik kurang terlibat secara aktif pada proses pembelajaran (Ristanto, 2010).

Selanjutnya dilakukan analisis peserta didik. Berdasarkan hasil wawancara dan pengamatan dengan pendidik kimia dapat disimpulkan bahwa ketika proses pembelajaran berlangsung, setiap siswa memiliki kecepatan dan kemampuan yang berbeda-beda dalam menerima materi pembelajaran. Selain itu, sebagian minat belajar kimia para peserta didik masih kurang. Hal ini dibuktikan dengan peserta didik yang terlihat mengabaikan pelajaran dan asyik mengobrol dengan peserta didik lain saat pembelajaran kimia berlangsung. Kondisi seperti ini relatif sulit untuk diubah. Akan tetapi ada beberapa cara yang dapat digunakan pendidik untuk dapat mengaktifkan peserta didik, salah satunya dengan penggunaan LKPD.

Langkah selanjutnya melakukan analisis konsep, analisis tugas, dan spesifikasi tujuan pembelajaran. Dalam hal ini materi pembelajaran yang dipilih adalah asam basa dan titrasi dengan enam sub pokok bahasan yang terdiri dari: (1) konsep asam basa, (2) indikator asam basa, (3) derajat keasaman, (4) konsep titrasi asam basa, (5) praktikum asam basa, dan (6) penentuan konsentrasi cuka. Pada spesifikasi tujuan pembelajaran dilakukan analisis kompetensi inti dan kompetensi dasar. Kompetensi dasar yang dipilih adalah KD 3.10, 4.10, 3.11, dan 4.11 yang merupakan materi asam basa dan titrasi. Aktivitas pembelajaran dalam LKPD kimia yang dikembangkan disesuaikan dengan sintaks pembelajaran inkuiri terbimbing.

Tahap perancangan terdiri dari penyusunan tes, pemilihan media yang sesuai dengan tujuan, pemilihan format, dan rancangan awal. Penyusunan tes dilakukan untuk menentukan bagaimana penilaian pemahaman konsep peserta didik, kapan penilaian dilakukan, dan bagaimana penilaiannya. Penilaian pemahaman konsep peserta didik terhadap pembelajaran dilakukan dengan dua tahap. Tahap awal berupa pretest yang diberikan sebelum pertemuan awal dimulai sedangkan pada tahap akhir berupa posttest yang diberikan setelah materi pembelajaran asam basa dan titrasi selesai. Soal pretest dan posttest yang diujikan berjumlah 20 butir soal pilihan ganda dengan dimensi kognitif meliputi C1, C2, C3, dan C4.

Media yang digunakan untuk menyampaikan materi pelajaran adalah modul dan buku paket. Meskipun pembelajaran dilakukan dengan menggunakan lembar kerja peserta didik, media sebagai pendukung dalam kegiatan belajar dengan modul dan buku paket tetap diperlukan. Pertimbangan pemilihan modul dan buku paket sebagai media pendukung dikarenakan penggunaan modul dan buku paket memperkuat pembelajaran yang memerlukan praktikum.

Format lembar kerja peserta didik digunakan untuk medesain LKPD sesuai dengan kebutuhan yang ada pada tahap perencanaan. Desain LKPD menggunakan format pembelajaran berbasis inkuiri terbimbing. Desain LKPD yang ditentukan peneliti dapat dilihat pada Tabel 4 .

Tabel 4. Outline LKPD Berbasis Inkuiri Terbimbing

\begin{tabular}{|c|c|c|c|}
\hline No & Bagian Awal & Bagian Isi & $\begin{array}{l}\text { Bagian } \\
\text { Akhir }\end{array}$ \\
\hline 1 & Halaman sampul & Nomor LKPD & Daftar \\
\hline 2 & Kata Pengantar & Judul Materi & Pustaka \\
\hline 3 & Daftar Isi & Kolom Identitas & \\
\hline 4 & Pendahuluan & Tujuan Pembelajaran & \\
\hline 5 & $\begin{array}{l}\text { Petunjuk } \\
\text { Penggunaan } \\
\text { LKPD }\end{array}$ & Orientasi & \\
\hline 6 & Kompetensi Inti & $\begin{array}{l}\text { Merumuskan } \\
\text { Masalah } \\
\text { Mengajukan } \\
\text { Hipotesis } \\
\text { Mengumpulkan Data } \\
\text { Menganalisis Data }\end{array}$ & \\
\hline 7 & $\begin{array}{l}\text { Kompetensi } \\
\text { Dasar }\end{array}$ & Menyimpulkan & \\
\hline
\end{tabular}

Rancangan LKPD dihasilkan peneliti sebagai produk awal LKPD berbasis inkuiri terbimbing. Desain sampul LKPD dapat dilihat pada Gambar 2. 


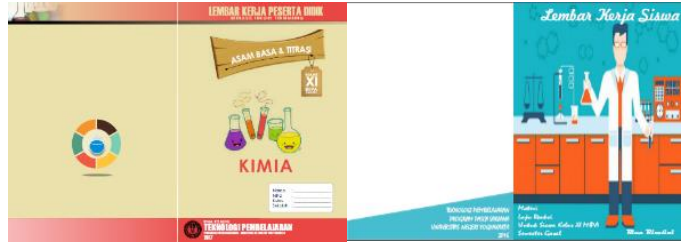

Gambar 2. Desain Sampul LKPD Sebelum dan Sesudah Revisi

Bagian inti LKPD dikemas sedemikian rupa sehingga peserta didik dapat membangun pengetahuannya sendiri dan berpartisipasi secara aktif pada proses pembelajaran. Penyajian materi dalam LKPD diintegrasikan pada tahapan inkuiri terbimbing yang terdiri dari menghadapi masalah, pertanyaan dan pengumpulan data, eksperimen dan menghasilkan hipotesis. Berikut contoh tampilan bagian inti modul.
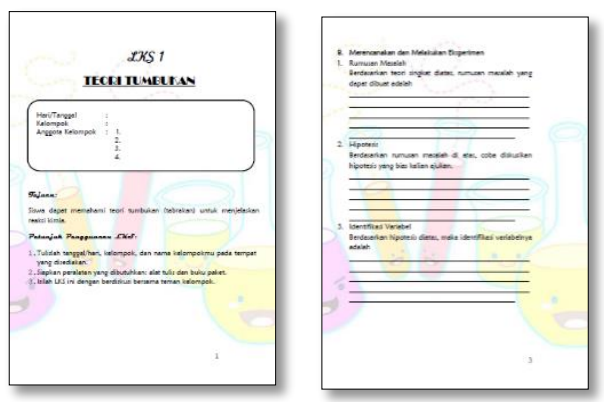

Gambar 3. Desain Bagian Inti LKPD Sebelum Revisi
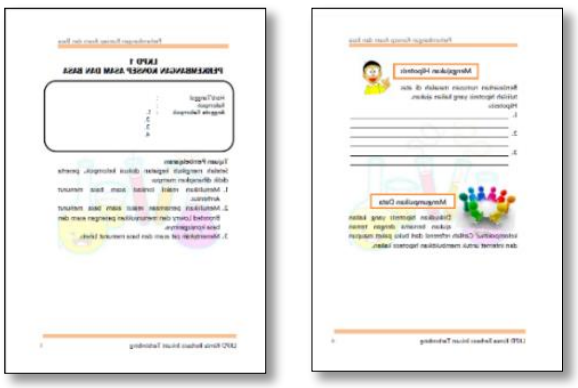

Gambar 4. Desain Bagian Inti LKPD Setelah Revisi

Bagian akhir LKPD berupa daftar pustaka. Produk awal tidak memiliki daftar pustaka setelah direvisi sudah ada daftar pustaka.

Tahap pengembangan terdiri dari validasi ahli dan simulasi LKPD. Validasi instrumen dilakukan dengan tujuan untuk mendapatkan instrumen yang valid dan layak digunakan dalam menilai produk lembar kerja peserta didik. Komponen yang dinilai dalam instrumen penelitian meliputi aspek pernyataan sesuai dengan kisi-kisi instrumen, aspek kesesuaian isi/materi, aspek kesesuaian dengan syarat dikdaktik, aspek kesesuaian dengan syarat konstruksi, aspek kesesuaian dengan syarat teknis, dan aspek kesesuaian dengan pembelajaran berbasis inkuiri terbimbing. Data hasil penilaian terhadap instrumen penelitian disajikan dalam Tabel 5.

Tabel 5. Hasil Analisis Data Validasi Instrumen Penelitian

\begin{tabular}{|c|c|c|c|}
\hline No & Aspek Penilaian & $\begin{array}{l}\text { Rerata } \\
\text { Skor }\end{array}$ & Kriteria \\
\hline 1 & $\begin{array}{l}\text { Pernyataan sesuai dengan } \\
\text { kisi-kisi instrumen }\end{array}$ & 5,00 & $\begin{array}{l}\text { Layak diguna- } \\
\text { kan dengan }\end{array}$ \\
\hline 2 & Kesesuaian Isi/Materi & 4,00 & revisi \\
\hline 3 & $\begin{array}{l}\text { Kesesuaian dengan Syarat } \\
\text { Dikdaktik }\end{array}$ & 5,00 & \\
\hline 4 & $\begin{array}{l}\text { Kesesuaian dengan Syarat } \\
\text { Konstruksi }\end{array}$ & 5,00 & \\
\hline 5 & $\begin{array}{l}\text { Kesesuaian dengan Syarat } \\
\text { Teknis }\end{array}$ & 4,00 & \\
\hline 6 & $\begin{array}{l}\text { Kesesuaian dengan } \\
\text { pembelajaran berbasis } \\
\text { inkuiri terbimbing }\end{array}$ & 4,00 & \\
\hline
\end{tabular}

Dari keseluruhan aspek yang dinilai oleh validator, instrumen penelitian ini dikatakan layak untuk digunakan dengan revisi karena keseluruhan aspek dalam instrumen berada dalam kategori layak digunakan dengan revisi. Akan tetapi bagian yang perlu, direvisi terlebih dahulu sebelum digunakan.

Validasi media dilakukan untuk mengukur kelayakan lembar kerja peserta didik berbasis inkuiri terbimbing ditinjau dari aspek media. Kedua ahli media diberikan instrumen untuk menilai kualitas media secara keseluruhan. Validasi media terdiri dari empat aspek yang dievaluasi. Pertama aspek kesesuaian isi/materi, kedua aspek kesesuaian dengan syarat dikdaktik, ketiga kesesuaian dengan syarat konstruksi, dan keempat kesesuaian dengan syarat teknis. 
Validasi ahli materi dilakukan untuk mengukur dan menilai derajat keabsahan materi dan isi lembar kerja peserta didik berbasis inkuiri yang dikembangkan. Secara umum, ada lima aspek yang divalidasi oleh ahli materi yaitu aspek kesesuaian isi/materi, kesesuaian dengan syarat dikdaktik, kesesuaian dengan syarat konstruksi, kesesuaian dengan syarat teknis, dan kesesuaian dengan pembelajaran berbasis inkuiri terbimbing.

Selanjutnya dilakukan simulasi lembar kerja peserta didik berbasis inkuiri terbimbing oleh pendidik dengan tujuan untuk memberi gambaran kepada para pendidik tentang pelaksanaan pembelajaran menggunakan model pembelajaran inkuiri terbimbing sekaligus diperoleh masukan tentang kesesuaian alokasi waktu penggunaan LKPD. Hasil simulasi dengan pendidik diperoleh hasil bahwa model pembelajaran inkuiri terbimbing dapat diterapkan di dalam kelas yang menjadi subjek penelitian.

\section{Hasil Uji Coba Produk}

Menurut Nieveen (1999, p. 87) ada tiga aspek kriteria kualitas suatu produk yaitu layak, praktis, dan efektif. Salah satu kriteria utama untuk menentukan apakah produk yang dikembangkan dinyatakan layak adalah hasil validasi para ahli media dan materi.

Hasil validasi media dari dua ahli media dapat dilihat pada Gambar 5.

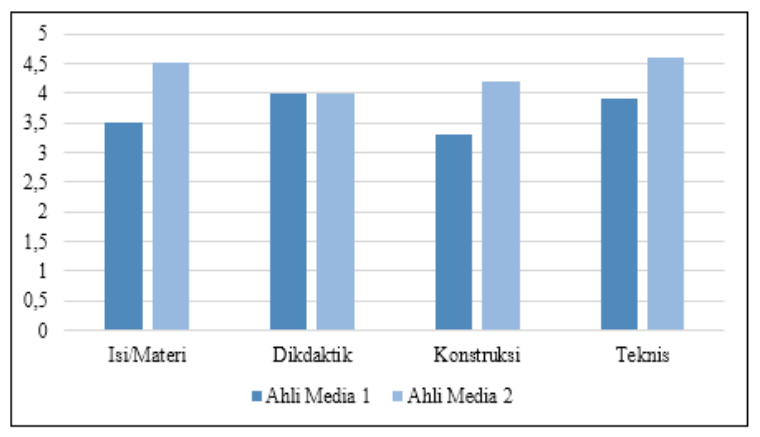

Gambar 5. Diagram Penilaian Dua Ahli Media

Data penilaian dua ahli media pada keseluruhan aspek diperoleh rata rata 3,99 dengan kriteria layak. Rerata skor tersebut dijabarkan dalam pencapaian rerata skor masing-masing aspek diantaranya kesesuaian isi/materi yang terdiri dari dua indikator mencapai rerata skor 4,00 berada dalam kategori layak. Aspek kesesuaian dengan syarat dikdaktik dengan satu indikator memperoleh skor 4,00 juga berada dalam kategori layak. Selanjutnya, aspek kesesuaian dengan syarat konstruksi yang terdiri dari enam indikator mencapai rerata skor 3,75 kategori layak dan aspek kesesuaian dengan syarat teknis memperoleh rerata skor 4,21 juga berada dalam kategori layak.

Hasil validasi materi dari dua ahli materi dapat dilihat pada Gambar 6.

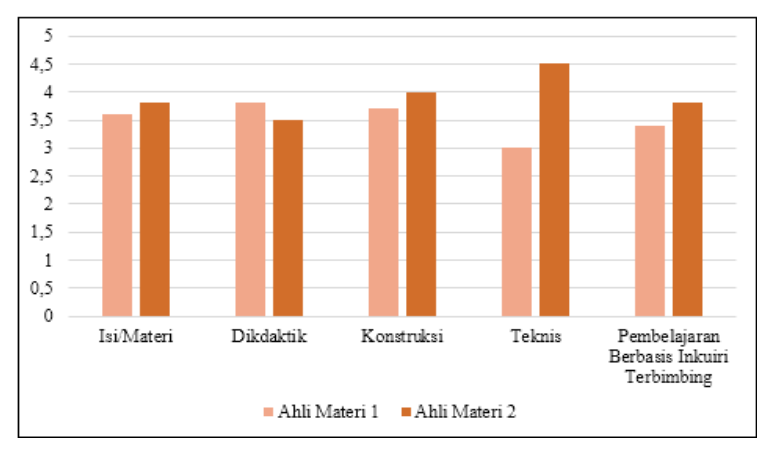

Gambar 6. Diagram Penilaian Dua Ahli

\section{Materi}

Rata-rata skor yang diperoleh dari keseluruhan aspek adalah 3,82 dengan kriteria layak. Aspek kesesuaian isi/materi mencapai skor rata-rata 3,86 dengan kategori layak, kesesuaian dengan syarat dikdaktik dengan rerata skor 3,63 kategori layak, kesesuaian dengan syarat konstruksi memperoleh skor 3,83 berada dalam kategori layak, kesesuaian dengan syarat teknis dengan rerata skor 4,00 kategori layak, dan kesesuaian dengan pembelajaran berbasis inkuiri terbimbing diberi skor 3,80 kategori layak.

Setelah dinyatakan layak oleh para ahli media dan materi dilanjutkan dengan uji coba kelompok kecil. Hasil dari uji coba kelompok kecil digunakan sebagai masukan kepada peneliti tentang keterbacaan produk yang dikembangkan sebelum diujicobakan di lapangan. Data mengenai respon peserta didik pada uji coba kelompok kecil disajikan dalam Tabel 6 . 
Tabel 6. Hasil Skor Respon Peserta Didik pada Uji Coba Kelompok kecil

\begin{tabular}{clcc}
\hline No & Aspek Penilaian & $\begin{array}{c}\text { Rerata } \\
\text { Skor }\end{array}$ & Kriteria \\
\hline 1 & Materi/Pembelajaran & 4,58 & Sangat Baik \\
2 & Tampilan & 4,22 & Sangat Baik \\
3 & Bahasa & 4,29 & Sangat Baik \\
& Total Skor & 4,37 & Sangat Baik \\
\hline
\end{tabular}

Berdasarkan hasil penilaian respon peserta didik terhadap LKPD diperoleh rata-rata 4,37 dengan kriteria sangat baik. Hal ini menunjukkan bahwa LKPD yang dikembangkan dapat diujicobakan di lapangan.

Hasil uji coba lapangan digunakan untuk melihat kepraktisan dan keefektifan dari lembar kerja peserta didik berbasis inkuiri terbimbing yang dikembangkan.

Aspek kepraktisan ditentukan dari keterlaksanaan pembelajaran berbasis inkuiri terbimbing dan respon para peserta didik yang menyatakan bahwa LKPD ini mudah digunakan dalam pembelajaran.

Hasil analisis observasi keterlaksanaan pembelajaran inkuiri terbimbing oleh pendidik dan peserta didik selama tiga kali pertemuan secara visual dapat dilihat pada Gambar 7.

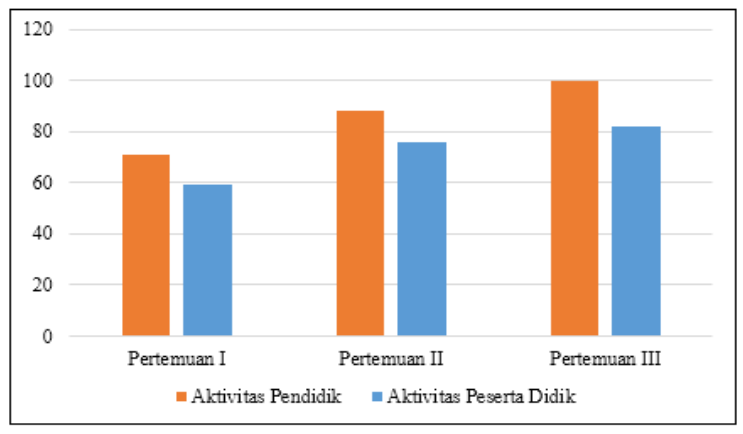

Gambar 7. Diagram Persentase

Keterlaksanaan Sintaks Inkuiri Terbimbing

Hasil analisis dari ketiga pertemuan tersebut diperoleh persentase aktivitas pendidik sebesar $86 \%$ berada dalam kategori sangat baik dan aktivitas peserta didik sebesar $73 \%$ kategori baik. Persentase aktivitas peserta didik lebih kecil dibandingkan ativitas pendidik karena pendidik lebih mampu melaksanakan ativitas sesuai dengan ske- nario pembelajaran yang dirancang sendiri, sedang peserta didik hanya mengikuti rancangan yang telah dibuat sesuai dengan instruksi dari pendidik.

Angket respon peserta didik berisi beberapa pernyataan tentang respon terhadap bahasa, tampilan, dan materi/pembelajaran kimia. Angket dalam penelitian ini terdiri dari 17 pernyataan positif dan negatif. Pengolahan data angket merujuk pada skala Likert, untuk pernyataan positif persentase jawaban sangat setuju dan setuju semakin besar maka hasilnya semakin baik. Sedangkan untuk pernyataan negatif, semakin besar persentase jawaban tidak setuju dan kurang setuju maka hasilnya semakin baik.

Hasil analisis angket respon untuk pernyataan positif dapat dilihat pada Tabel 7.

Tabel 7. Hasil Respon Pernyataan Positif

\begin{tabular}{crl}
\hline Pernyataan & $\begin{array}{r}\text { Rerata } \\
\text { Skor }\end{array}$ & Ket. \\
\hline 1 & 3,70 & Sangat Setuju \\
2 & 3,50 & Setuju \\
4 & 3,55 & Sangat Setuju \\
5 & 3,60 & Sangat Setuju \\
6 & 3,40 & Setuju \\
7 & 3,65 & Sangat Setuju \\
8 & 3,40 & Setuju \\
10 & 3,60 & Sangat Setuju \\
12 & 3,35 & Setuju \\
16 & 3,80 & Sangat Setuju \\
Rata-rata & 3,56 & Sangat Setuju \\
\hline
\end{tabular}

Hasil analisis angket respon untuk pernyataan negatif dapat dilihat pada Tabel 8.

Tabel 8. Hasil Respon Pernyataan Negatif

\begin{tabular}{crl}
\hline Pernyataan & $\begin{array}{r}\text { Rerata } \\
\text { Skor }\end{array}$ & Ket. \\
\hline 3 & 1,55 & Tidak Setuju \\
9 & 1,35 & Sangat Tidak Setuju \\
11 & 2,55 & Setuju \\
13 & 1,55 & Tidak Setuju \\
14 & 1,50 & Sangat Tidak Setuju \\
15 & 1,65 & Tidak Setuju \\
17 & 1,40 & Sangat Tidak Setuju \\
Rata-rata & 1,65 & Tidak Setuju \\
\hline
\end{tabular}


Berdasarkan kedua tabel diatas, pernyataan positif memperoleh rerata skor 3,56 kategori sangat setuju sedangkan pernyataan negatif memperoleh rerata skor 1,65 kategori tidak setuju. Dengan demikian dapat disimpulkan bahwa lembar kerja peserta didik yang dikembangkan dengan pembelajaran berbasis inkuiri terbimbing sudah dinilai praktis berdasarkan indikator respon terhadap kebahasaan, tampilan, dan materi/pembelajaran secara keseluruhan berada dalam kategori sangat baik.

Aspek keefektifan lembar kerja peserta didik berbasis inkuiri terbimbing yang dikembangkan diukur dari nilai pretest dan posttest antara kelas eksperimen dan kelas kontrol. Gain skor yang diperoleh kemudian diuji t. Tujuannya untuk mengetahui ada tidaknya perbedaan kenaikan gain skor pada kedua kelas tersebut. Dikatakan signifikan apabila $\mathrm{t}$ hitung $>\mathrm{t}$ tabel pada taraf signifikansi $5 \%$ dan $p<0,05$. Hasil analisis uji $t$ kenaikan gain skor dapat dilihat pada Tabel 9.

Tabel 9. Uji t Kenaikan Gain Skor Kelas Eksperimen dan Kelas Kontrol

\begin{tabular}{clllllr}
\hline & $\begin{array}{l}\text { Levene's Test For } \\
\text { Equality of } \\
\text { Variances }\end{array}$ & & & & & \\
\cline { 2 - 8 } & $\mathrm{F}$ & & Sig. & $\mathrm{t}$ & $\mathrm{df}$ & Sig. (2-tailed) \\
\cline { 2 - 7 } $\begin{array}{c}\text { Nilai Equal variances } \\
\text { assumed } \\
\begin{array}{l}\text { Equal variances } \\
\text { not assumed }\end{array}\end{array}$ & & .455 & .504 & 4.895 & 38 & .000 \\
\hline
\end{tabular}

Berdasarkan hasil perhitungan independent sample $\mathrm{t}$-test diperoleh nilai $\mathrm{t}$ hitung sebesar 4,89 dengan signifikansi 0,000. Nilai $\mathrm{t}_{\text {tabel }}=2,09$. Jadi dapat disimpulkan bahwa $t_{\text {hitung }}>t_{\text {tabel }}(4,89>2,09)$ dan nilai signifikansinya 0,000 $<0,05$ sehingga dapat dikatakan terdapat perbedaan yang signifikan dalam peningkatan gain skor pada kelas eksperimen dan kelas kontrol.

Dengan demikian dapat disimpulkan bahwa lembar kerja peserta didik yang dikembangkan dengan pembelajaran berbasis inkuiri terbimbing efektif meningkatkan pemahaman konsep peserta didik pada materi kimia.

Pengembangan LKPD berbasis inkuiri terbimbing dipilih karena LKPD yang digunakan sekarang ini kurang mengaktifkan peserta didik dalam proses pembelajaran. Adapun pemilihan model inkuiri terbimbing dikarenakan walaupun perkembang-an kognitif siswa SMA sudah berada pada tahap operasional formal, akan tetapi sehingga secara psikologis belum stabil sehingga masih memerlukan bimbingan untuk membiasakannya dalam proses pencarian pengetahuan.

Menurut Darmodjo \& Kaligis (1993, p. 40), LKPD merupakan sarana pembelajaran yang dapat digunakan pendidik dalam meningkatkan keterlibatan atau aktivitas peserta didik dalam proses pembelajaran. Suatu LKPD yang berkualitas baik jika memenuhi beberapa syarat yaitu: (1) syarat didaktik, (2) syarat konstruksi, dan (3) syarat teknis.

Proses pengembangan lembar kerja peserta didik berbasis inkuiri terbimbing ini melewati beberapa tahapan uji coba, baik uji kelayakan dari ahli media dan materi maupun uji coba kepada peserta didik. Produk LKPD berbasis inkuiri terbimbing ini sudah layak menjadi produk akhir yang dapat disebarluaskan dan diimplementasikan kepada para pengguna. Kelayakan tersebut dilihat dari penilaian hampir semua tahapan memberi nilai dengan kategori "Layak". Hal ini sesuai dengan yang dijabarkan oleh Widjajanti (2010, p. 4) bahwa suatu LKPD dikatakan layak jika telah memenuhi kriteria kelayakan meliputi syarat didaktik, konstruksi, dan teknis.

LKPD berbasis inkuiri terbimbing ini praktis diterapkan dalam pembelajaran. Hal ini dibuktikan dengan hasil observasi keterlaksaan pembelajaran memperoleh rata-rata $86 \%$ dengan kategori sangat baik, artinya secara umum sintaks inkuiri terbimbing terlaksana sesuai dengan rancangan yang dibuat. Selain itu, angket respon peserta didik juga berada dalam kategori sangat baik, artinya peserta didik merespon baik LKPD yang dikembangkan.

Penggunaan LKPD ini juga efektif dalam meningkatkan pemahaman konsep peserta didik dalam penguasaan materi asam basa dan titrasi. Hal ini dibuktikan 
dengan adanya perbedaan yang signifikan antara kelas eksperimen dan kelas kontrol. Nilai signifikansinya $0,000<0,05$. Hal ini menujukkan ada perbedaan yang signifikan antara gain skor yang diperoleh peserta didik sebelum dan setelah menggunakan LKPD ini. Berdasarkan perbedaan signifikansi tersebut, maka disimpulkan bahwa LKPD yang dikembangkan dinyatakan efektif untuk digunakan dalam pembelajaran. Hal ini sesuai dengan pernyataan Kuslan \& Stone (1969, p. 140) yang mengemukakan bahwa pembelajaran inkuiri "can increases the intelectual potency of the learner and expedites memory processing".

\section{Simpulan}

Berdasarkan hasil penelitian dan pengembangan, dapat disimpulkan bahwa produk LKPD berbasis inkuiri terbimbing pada mata pelajaran kimia kelas XI IPA SMA materi asam basa dan titrasi adalah sebagai berikut. Pertama, LKPD kimia berbasis inkuiri yang dihasilkan dinilai layak digunakan ditinjau dari penilaian para ahli media, ahli materi, dan praktisi kimia. Kelayakan tersebut dapat dilihat dari rerata skor penilaian ahli media sebesar 3,99 dengan kategori layak dan rerata skor ahli materi serta praktisi kimia sebesar 3,82 berada dalam kategori layak.

Kedua, kepraktisan dari LKPD merujuk pada hasil pengamatan keterlaksanaan sintaks inkuiri terbimbing dan respon peserta didik terhadap LKPD. Hasil observasi keterlaksanan sintaks inkuiri terbimbing selama tiga kali pertemuan sebesar $86 \%$ dengan kategori sangat baik. Sedangkan respon peserta didik terhadap LKPD berada dalam kategori sangat baik.

Ketiga, keefektifan dari LKPD dilihat dari hasil perolehan pretest dan posttest kelas eksperimen dan kelas kontrol. Setelah dilakukan perhitungan independent sample t-test diperoleh nilai signifikansi sebesar 0,000 . Hal ini membuktikan bahwa sig < 0,05 ada perbedan yang signifikan antara kelas eksperimen dan kelas kontrol.
Berangkat dari hasil penelitian yang diperoleh, maka ada beberapa saran yang disampaikan, diantaranya: (1) produk LKPD berbasis inkuiri terbimbing ini perlu diimplementasikan lebih lanjut pada cakupan yang lebih luas agar diketahui kelemahan dan kekurangannya dalam proses pembelajaran, (2) pendidik diharapkan mampu memanfaatkan LKPD ini untuk memfasilitasi alternatif media pembelajaran peserta didik, (3) materi yang disajikan dalam LKPD sebaiknya dikembangkan juga untuk materi yang lain terutama materi yang memerlukan penemuan konsep.

\section{Daftar Pustaka}

Darmodjo, H., \& Kaligis, J. R. E. (1993). Pendidikan IPA II. Jakarta: Departemen Pendidikan dan Kebudayaan Badan Penelitian dan Pengembangan Pendidikan dan Kebudayaan Republik Indonesia.

Hake, R. R. (1998). Interactive-engagement versus traditional methods: A sixthousand-student survey of mechanics test data for introductory physics courses. American Journal of Physics, 66(1), 64-74. https:// doi.org/10.1119/1.18809

Hamalik, O. (2011). Proses belajar mengajar. Jakarta: Bumi Aksara.

Kuslan, L. I., \& Stone, A. H. (1969). Teaching children science: An approach. USA: Wadsworth Publishing Company.

Lukman, L., \& Ishartiwi, I. (2014). Pengembangan bahan ajar dengan model mind map untuk pembelajaran ilmu pengetahuan sosial SMP. Jurnal Inovasi Teknologi Pendidikan, 1(2), 109122. https:// doi.org/10.21831/tp.v1i2.252 3

Menteri Pendidikan Nasional. Peraturan menteri pendidikan nasional nomor 22 tahun 2006 standar isi (2006).

Nieveen, N. (1999). Prototyping to reach 
product quality. In J. van den Akker, R. M. Branch, K. Gustafson, N. Nieveen, \& T. Plomp (Eds.), Design approaches and tools in education and training. Boston: Springer.

Ristanto, R. H. (2010). Pembelajaran berbasis inkuiri terbimbing dengan multimedia dan lingkungaan riil ditinjau dari motivasi berprestasi dan kemampuan awal. Tesis. Unpublished. Universitas Sebelas Maret.

Sasongko, N. D., \& Haryanto, H. (2016). Keefektifan metode inquiry terhadap keaktifan dan hasil belajar siswa kelas X pembelajaran Kimia. Jurnal Inovasi Teknologi Pendidikan, 3(1), 40. https://doi.org/10.21831/tp.v3i1.827 7

Sujudi. (2011). Pendekatan inkuiri untuk mengembangkan kemampuan bertanya siswa dalam pembelajaran Fisika. Jurnal Fisika Dan Pembelajarannya, 15(1).
Thiagarajan, S., Semmel, D. S., \& Semmel, M. I. (1974). Instructional development for training teachers of exceptional children. Bloomington: Indiana University.

Trianto. (2007). Model pembelajaran terpadu. Jakarta: Bumi Aksara.

Trianto. (2012). Model pembelajaran terpadu. Konsep, stategi, dan implementasinya dalam KTSP. Jakarta: Bumi Aksara.

Trowbridge, L., \& Bybee, R. W. (1996). Teaching secondary school science (6th ed.). New Jersey: Merrill/Prentice Hall.

Widjajanti, E. (2010). Penilaian lembar kerja siswa materi konsep atom, ion dan molekul. In Pelatihan Penilaian Lembar Kerja Siswa bagi Guru Mata Pelajaran Kimia. Universitas Negeri Yogyakarta.

Zulfiani, Feronika, T., \& Kinkin, S. (2009). Strategi pembelajaran sains. Jakarta: Lembaga Penelitian UIN Jakarta. 